\title{
Factors Determining the Characteristics of Cocoa Soil in Sulawesi
}

\author{
Erwin Prastowo ${ }^{* 1)}$ and John Bako Baon ${ }^{1)}$ \\ ${ }^{1)}$ Indonesian Coffee and Cocoa Research Institute, Jl. PB Sudirman 90, Jember 68118, Indonesia \\ ${ }^{*}$ Corresponding author: erwinprastowo@gmail.com \\ Received: 4 December 2019/ Accepted: 14 Januari 2020
}

\begin{abstract}
Sulawesi exhibits unique land characteristics as a result of complex geological and geomorphological processes. The information related to what extent of these processes affect regional soil characteristics is still limited. An investigation was performed on cocoa farms from three major cocoa producers, i.e. South Sulawesi, Central Sulawesi, and Southeast Sulawesi. A research was done to point out the key variables contributing to cocoa soil characteristics. Soil survey was performed based on available local information to collect top soil composite samples, i.e. $0-30 \mathrm{~cm}$ depth, in the circle of cocoa stand within $50-75 \mathrm{~cm}$ radius. A routine soil analysis was done to evaluate soil texture, organic carbon $(\mathrm{C})$, total nitrogen, $\mathrm{K}, \mathrm{Ca}, \mathrm{Mg}$, soil $\mathrm{pH}\left(\mathrm{H}_{2} \mathrm{O}\right)$, and some micronutrients, i.e. $\mathrm{Fe}, \mathrm{Cu}$, and $\mathrm{Zn}$. To simplify the complexity, the multivariate data was submitted into principal component analysis (PCA). Additional mapping of soil variable gradient through inverse distance weighting (IDW) interpolation was included in the analysis to improve our interpretations. Data show that the variability for almost all investigated variables is high with coefficient of variation (CV) of up to about $118 \%$ for Fe. While low variability with $\mathrm{CV}$ about $10 \%$ was observed for soil $\mathrm{pH}\left(\mathrm{H}_{2} \mathrm{O}\right)$. The PCA demonstrates that the first five principal components (PCs) account for $56.89 \%$ of variance in the original variables. Two factors to be considered to explain the variation in the PCs was soil texture and parent material. Further analyses exhibit an association of sand, silt, and clay fractions to Southeast, Central, and South Sulawesi. Mineral compositions, such as $\mathrm{K}, \mathrm{Ca}, \mathrm{Mg}, \mathrm{Fe}$, and $\mathrm{Zn}$, exhibit an important contribution to the parent material factor as they define the variability in the PCs. Additionally, the analysis of gradient maps may indicate the two physical environmental conditions, i.e. landform and geological setting, contribute to the specific characteristics of cocoa soil.
\end{abstract}

Keywords: Cocoa soil, Sulawesi, soil characteristics, soil parent material

\section{INTRODUCTION}

Sulawesi island plays a significant role as a main cocoa producer in Indonesia. It contributes to about $60 \%$ out of total national production (SDECS, 2018). Geologically, Sulawesi is a meeting point among three contrasting major plates actively moving in differing directions up to present day, i.e. Indian-Australian Plate,
Pacific plate, and Eurasian plate (van Bemmelen, 1949; Martosuwito, 2012). Complex geological processes in this area (Katili, 1978), may give rise to a high variability in terms of soil development works and characteristics mainly as a result of variation in their parent rock origins. Consequently, it may provide a subsequent variability with respect to mineral compositions though climatic conditions in a limited 
size of area is likely similar (Safiuddin et al., 2011).

Various parent rock types and geological formations have been identified in Sulawesi (Sukamto, 1982; Simandjuntak et al., 1991; Simandjuntak et al., 1997; Rusmana et al., 1993a; Rusmana et al., 1993b; Simandjuntak et al., 1993a; Simandjuntak et al., 1993b). To what extent in terms of their effects, in a large scale, to soil behaviors, such as the inherent level of cocoa soil fertility, are still unclear due to the limitation scientific reports available to the best our knowledge.

In the limited area on schist derived parent materials in Southeast Sulawesi, a land evaluation for cocoa revealed that the low level of soil $\mathrm{pH}$ and organic carbon (C) content were still the main constraints (Yatno et al., 2015). The recommendation following this report may be pointing out the application of lime materials and organic fertilizers to improve to a satisfactory level. Different works focusing on pedogenic processes through profile morphology observations have been performed to characterize the parent rocks on lacustrine deposits in North Sulawesi, Gorontalo, Central Sulawesi, and South Sulawesi (Hikmatullah \& Suparto, 2014), ultramafic parent rocks in Southeast Sulawesi (Alam et al., 2012), and dunite basalt in South Sulawesi (Sunarminto, 2000). Their findings relate parent rock characteristics to soil types undergoing the development processes.

Given that the characteristics of cocoa soil in Sulawesi may be attributable to various environmental factors, the main variable keys that control these behaviors remains unclear. The interactive effect due to climate variable (Wagai et al., 2008) will be supposed to be negligible as they may occupy in the limited range of area from low to middle of altitude, below $600 \mathrm{~m}$ asl. based on our data records. A former report explored the soil fertility status of cocoa soils in Central Sulawesi without taking into account the parent material composition of soil at which cocoa farms established (Maskar et al., 1999). A couple years later, a research found the importance of soil parent materials to affect cocoa yields (Arshad et al., 2016).

A typical multivariate data collected after soil survey may provide an additional complexity on pointing out the main key variables contributing to cocoa soil characteristics. However, the use of multivariate statistical analysis may get rid of such problem since allows the simultaneous analysis using multiple variables. This tool may not be really popular in the soil science field despite some former work reports (Kosaki \& Juo, 1989; Buurman et al., 2008; Fernandez-Moya et al., 2014).

The multivariate analyses that work on variables, minimize their number, and identify the important variables in the middle of the sample variations called principal component analysis (McKillup, 2012). This analysis transforms multivariate data set to a new variable ones that are linear combinations of the original variables (Everitt \& Hothorn, 2011). A new set of variables, called principal components, is interpreted through 1) factor scores, providing new coordinates of the factor space with the location of objects, and 2) factor loadings, determining on the relationship among the variables (Astel et al., 2011).

This paper will discuss the characteristics of cocoa soils developed on various parent rocks in Central, South, and Southeast Sulawesi. The use of some variables, i.e. clay, organic $\mathrm{C}$, total $\mathrm{N}$, basic minerals, i.e. $\mathrm{K}, \mathrm{Ca}$, and $\mathrm{Mg}$, soil acidity, i.e. $\mathrm{pH}\left(\mathrm{H}_{2} \mathrm{O}\right)$ and $\mathrm{SO}_{4}$, may provide a specific information related to field cocoa management, and soil-environmental factors. To improve the interpretation, the principal component analysis was applied to extract some important soil variables, and 
identify the key variable that control the characteristics. Additionally, maps are provided to look at the gradient of soil characteristics across the study area.

\section{MATERIALS AND METHODS}

\section{Description of Study Area}

A field study in the cocoa farms was investigated in the three major cocoa producers in Sulawesi Island, i.e. South Sulawesi, Central Sulawesi, and Southeast Sulawesi. Data collected for evaluation should allow for some areas with clear environmental conditions, i.e. GPS coordinate, physiography, slope and altitude, and laboratory set of data, i.e. soil physical and chemical analysis. In every regions, subsamples were obtained from some district level such as Bone, Soppeng, Sidrap, Enrekang, Luwu, South Luwu, and East Luwu in South Sulawesi; Morowali, Banggai, and Tojo Una-Una in Central Sulawesi; and Konawe, Kolaka, North Kolaka, South Kolaka, and Muna in Southeast Sulawesi.

The investigated cocoa farms showed a high variety in the context of field agronomic practices including replanted, intensified, and rehabilitated area. Furthermore, every single farm may be subject to different fertilization history, pruning management, and pest-disease control following their traditional way with respect to agricultural practices.

\section{Physiography and Climate}

Sulawesi is the most mountainous large islands in archipelago (van Bemmelen, 1949), as mostly covered by mountainland. Additionally, different landforms include coastal lowland and intermontane plains, to some lesser extent, making up a large scale of landforms. The latter two may have provided for the majority of agricultural areas in this region. Among three different regions investigated,
South Sulawesi may be occupied by a majority of low to middle range of altitude (Figure 1a). Our field works record the highest level for cocoa farms at about $600 \mathrm{~m}$ asl., in the low to middle slope of mountainland.

Digital elevation model (Figure 1a), obtained from 30 second resolution of SRTM dataset available at http://www.diva-gis.org, shows the dominant mountainous area with altitude $>1000 \mathrm{~m}$ occupying in the western part of South-, and Southeast Sulawesi. Conversely, it is situated, mostly, in the middle of island for western part of Central Sulawesi. Climate map, with 2.5 minutes spatial resolution (Fick \& Hijmans, 2017), shows that the most likely of the study area being subjected to an annual average temperature of about $28^{\circ} \mathrm{C}$ (Figure 1b), and to some lesser extent for highland to the east of South-, and Southeast Sulawesi, and Central Sulawesi posing a temperature down to below $22^{\circ} \mathrm{C}$. The maps (Figure 1a, and 1b) may indicate a typical connection between elevations, and mean annual temperature. Similarly, it may also show the association between elevations and rainfall yet with observed anomalous to some extent mainly in the South Sulawesi. The annual rainfall $900-2600 \mathrm{~mm}$ is distributed through the majority of area, and increasing up to $4600 \mathrm{~mm}$ in the highland to the east of South Sulawesi. The highest rainfall is recorded in the coastal area close to Makassar of up to $6200 \mathrm{~mm}^{\text {year }}{ }^{-1}$ (Figure 1c).

\section{Geological Setting}

Geology of Sulawesi provides a geotectonic importance as a result of East Asiatic Island arcs and great Sunda Mountain System (van Bemmelen, 1949). The geology of Southeast-, Central-, and South Sulawesi are characterized by various rock compositions derived from different formations. Based on geological maps, the majority of parent materials for Southeast Sulawesi, from which the soil 
samples were collected, are developed on Palaeozoic metamorphics, Alluvium, Alangga, Boepinang and Tokala formations with mud, clay, sand, pebble, gravel, conglomerate, sandstone, marl, schist, gneiss, phyllite, quartzite, slate, clastic limestone, lithic sandstone wake, shale, and some marble as their main compositions (Rusmana et al., 1993b; Simandjuntak et al., 1993a; Simandjuntak et al., 1993b).

Furthermore, the identification of Central Sulawesi parent rock compositions on our sampling points exhibits some geological formations existed, i.e. Puna, Poso, Alluvial, Lonsio, and quaternary coral reef. They provide some materials such as pumiceous tuff, breccia, conglomerate and basaltic pillow lava, marl, conglomerate, sandstone, tuffaceous sandstone, silt, shale, calcareous claystone, sand, pebble, mud, reef limestone, and limestone (Rusmana et al., 1993a; Simandjuntak et al., 1991; Simandjuntak et al., 1997).

In the South Sulawesi, some geological formation has been identified on which cocoa farms have been established for over years for instance Aluvium, Saloso-Kalupang, Camba, Walane, Lava and Surficial Deposit. The parent rock compositions may include sand, pebble, mud, sedimentary rocks, marine sedimentary, sandstone, siltstone, tuff, marl, claystone, conglomerate, and limestone (Sukamto, 1982).

\section{Soil Sampling}

A systematical survey was performed based on available local information to collect top soil composite samples, i.e. $0-30 \mathrm{~cm}$ depth, from cocoa farms. They are in the large extent situated in the intermontane plains refer to the area in between the mountainland and lowland coastal area occupying, topographically, low to middle slope positions (Figure 1a). Exceptionally, the flat area in the southern part of South Sulawesi may, physiographically, provide a suitable cocoa farm area at a larger extent (Figure 1a). Yet, data statistics show that the larger cocoa farms are not existed in this region but Central Sulawesi, accounting for $29.83 \%$ out of totally $949.70 \mathrm{Ha}$ area in Sulawesi (SDECS, 2018).

The environmental conditions, i.e. slope, altitude, and landform, and GPS coordinate of cocoa farms were recorded to support the land evaluation. Additional information related to agronomic practices, i.e. land history, fertilization, irrigation practices, and planting design were obtained through a direct interview to the farm owners.

Totally, 517,77 , and 538 soil samples from different cocoa farms in South Sulawesi, Central Sulawesi, and Southeast Sulawesi, respectively, were identified and evaluated by facilitation of statistical tools. All soil samples were collected from at least 4 points in the circle of cocoa stand within $50-75 \mathrm{~cm}$ radius by soil auger. The total bulk samples, in the end, were mixed to obtain homogenous and representative composite samples. The size of final air-dried soil samples was reduced to at least one $\mathrm{kg}$ to facilitate the transportation from the field to the Laboratory in Indonesian Coffee and Cocoa Research Institute in Jember, East Java. The size of sample may depend on the requirement of analysis types, yet to our experience one $\mathrm{kg}$ is sufficient to cover all measurement required for cocoa land evaluation, and fertilizer recommendations. 


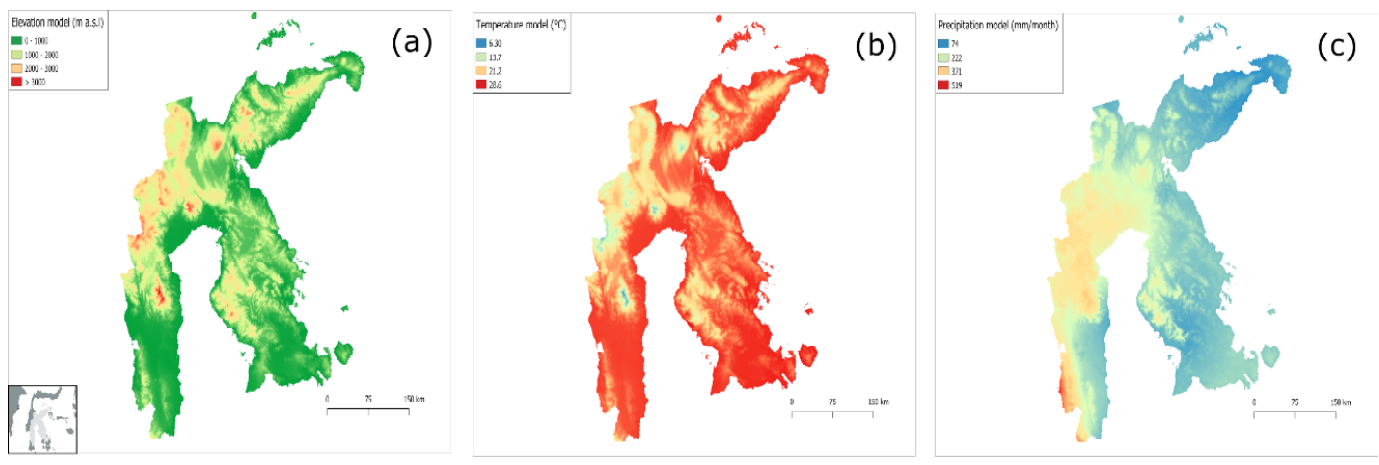

Figure 1. Map of digital elevation model (a), average annual temperature $\left({ }^{\circ} \mathrm{C}\right) 1970$ - 2000 (b), and monthly precipitation (mm) 1970-2000 of study area in Central, - South, and Southeast-Sulawesi. Inset map (left corner) indicates study area with respect to Sulawesi Island

\section{Laboratory Preparation and Analysis}

The air-dried soil samples were passed through $<2$ and $0.5 \mathrm{~mm}$ sieves in order to get a high homogeneity of particle size to facilitate the chemical analysis. The smaller size of soil particles are required for further specific analysis such as organic $\mathrm{C}$, but for general soil routine analysis a diameter $<2 \mathrm{~mm}$ size of samples is commonly used.

The routine soil analysis were carried out according to Indonesian Soil Research Institute (Eviati \& Sulaeman, 2009), including soil $\mathrm{pH}$ (1:2.5), soil texture by pipette methode, organic carbon (OC) by Walkley \& Black method, total nitrogen (TN) by micro kjeldahl method, exchangeable cations $(\mathrm{K}, \mathrm{Ca}, \mathrm{Mg})$ by $\mathrm{NH}_{4} \mathrm{OAc} \mathrm{pH} 7$ extract, and sulphur ( $\left.\mathrm{S}^{-}\right)$ applying $\mathrm{NaOAc}$ pH 4.8 extraction. Additional testing to reveal micronutrient contents, i.e. $\mathrm{Fe}, \mathrm{Cu}, \mathrm{Zn}$, by DTPA extraction. Micronutrients provide an important information especially related to their parent rock since, as residual minerals, they usually occur in the soil nearby their origins.

\section{Spatial Interpolation}

The measured variable values were interpolated by inverse distance weighting (IDW) method. This method assumes that value of an attribute at some unvisited point is a distance-weighted average of data points nearby the sampled points (Robinson \& Metternicht, 2006). Weights are usually inversely proportional to a power of distance which means that the rate of correlations and similarities between neighbors is proportional to the distance between them (Setianto \& Triandini, 2013). The unknown value is estimated as following (Karydas et al., 2009):

$$
\hat{z}_{\left(s_{0}\right)}=\sum_{i=1}^{N} \lambda_{i} z\left(s_{i}\right)
$$

with:

$\hat{z}_{\left(S_{0}\right)}=$ the estimation value of variable $\mathrm{z}$ for an un-sampled location $s_{0}$,

$\mathrm{N}=$ the number of measured sample points nearby the prediction location,

$\lambda_{\mathrm{i}} \quad=$ the weight of each measured point, and

$z\left(s_{i}\right) \quad=$ the observed value at location $s_{i}$ 
The weight $\lambda_{\mathrm{i}}$ are estimated based on the formula as below:

$$
\lambda_{i}=\frac{d_{i o}^{-p}}{\sum_{i=1}^{n} d_{i o}^{-p}}
$$

where $\sum_{i=1}^{n} \lambda_{i}=1$

$\mathrm{d}_{\mathrm{io}}=$ the distance between the un-sampled location $s_{o}$ and each sampled locations $s_{i}$.

$\mathrm{p}$ = power parameter; when distance increases the weight decreases exponentially.

\section{Statistical Analysis}

Basic summary statistics, i.e. mean, median, variance, coefficient of variation $(\mathrm{CV})$, skewness, and kurtosis were evaluated from totally 1131 soil samples collected from cocoa farms (Table 1). Data indicate a high variability of soil variables in the study areas which means that the soil characteristic difference among cocoa farms is likely pronounced. The high CV values for Fe of up to about $118 \%$ may be explained as a result of high variability of various parent material compositions across different regions. Conversely, the low $\mathrm{CV}$ values for soil $\mathrm{pH}\left(\mathrm{H}_{2} \mathrm{O}\right)$ of about $10 \%$, exceptionally, suggested the homogeneity condition among cocoa farms. The majority acid condition of soil may define the inherent properties of soil parent materials, will be discussed in the next sections. Similarly, a high variability for basic minerals such as $\mathrm{K}, \mathrm{Ca}$, and $\mathrm{Mg}$ (Table 1) may be attributable to the difference in parent material compositions. These minerals, at higher stage of soil development, are commonly accumulated especially in the lowland area in the large extent through the water flows from the upper slopes (Birkeland, 1999).

While skewness may confirm the symmetrical frequency distribution of data, kurtosis defines the "peakedness" (Swan \& Sandilands, 1995). Our data indicates a high positively skewed for some variables, i.e. TN, Fe, and Zn data distribution (Table 1). A less skewed variables such as clay, organic $\mathrm{C}, \mathrm{K}, \mathrm{SO}_{4}$, and $\mathrm{pH}\left(\mathrm{H}_{2} \mathrm{O}\right)$ indicate a fairly symmetrical data distribution. While the remaining variables, i.e. $\mathrm{Ca}, \mathrm{Mg}$, and $\mathrm{Cu}$ are moderately skewed. Furthermore, a high kurtosis for variables TN, Fe, and Zn may subsequently form a highly peaked distribution plot, and may be interpretable as the presence to some extent of outliers. The analysis reveals a corresponding high kurtosis with skewness for the same variables (Table 1).

Table 1. Statistical summary of soil parameters

\begin{tabular}{|c|c|c|c|c|c|c|c|}
\hline \multirow{2}{*}{ Soil parameter } & \multicolumn{7}{|c|}{ Statistical summary } \\
\hline & $\mathrm{N}$ & Mean & Median & Var. & $\mathrm{CV}(\%)$ & Skewness & Kurtosis \\
\hline Clay & 1131 & 35 & 35 & 397.82 & 56.22 & 0.29 & -0.59 \\
\hline Organic C & 1131 & 1.70 & 1.71 & 0.68 & 48.39 & 0.02 & -1.03 \\
\hline TN & 1131 & 0.17 & 0.16 & 0.00 & 35.44 & 4.01 & 65.70 \\
\hline $\mathrm{K}$ & 1131 & 0.78 & 0.79 & 0.05 & 29.66 & -0.42 & 2.06 \\
\hline $\mathrm{Ca}$ & 1131 & 9.79 & 8.76 & 14.73 & 39.20 & 0.81 & -0.31 \\
\hline $\mathrm{Mg}$ & 1131 & 6.20 & 5.17 & 7.57 & 44.39 & 0.70 & -0.65 \\
\hline $\mathrm{SO}_{4}$ & 1131 & 29 & 29 & 23.19 & 16.88 & 0.13 & -0.13 \\
\hline $\mathrm{Fe}^{4}$ & 1131 & 12 & 8 & 210.77 & 117.93 & 4.01 & 32.13 \\
\hline $\mathrm{Cu}$ & 1131 & 3 & 3 & 0.84 & 27.09 & 0.67 & 6.22 \\
\hline $\mathrm{Zn}$ & 1131 & 22 & 22 & 47.41 & 31.37 & 3.02 & 35.23 \\
\hline $\mathrm{pH}\left(\mathrm{H}_{2} \mathrm{O}\right)$ & 1131 & 5.47 & 5.50 & 0.42 & 11.80 & -0.28 & 1.20 \\
\hline
\end{tabular}


The question, however, may come up with respect to the main variable determining soil characteristics in the study areas. Due to the high heterogeneity of field conditions, the multivariate statistical analysis was performed to simplify the interpretation. To do so, data will be analyzed through PCA by extracting some important variables that explaining the variability of soil properties (Bitencourt et al., 2016). PCA is performed by retaining eigenvalues exceeding one. The analysis shows that the first five principal components account for $56.89 \%$ of the total variability (Table 2).

\section{RESULTS AND DISCUSSION}

\section{Cocoa Soil Characteristics}

We would evaluate the first five of important components from which a 56.89\% of cumulative variance from original variables is obtained. For the first component (PC1), the total variation may have been explained by some soil variables defined as higher than 0.20 to simplify our discussions, i.e. sand, clay, $\mathrm{K}, \mathrm{Ca}, \mathrm{Mg}, \mathrm{Fe}$, and $\mathrm{Cu}$ (Table 2). Sand occurs at the space towards to the right of plot while the remaining variables stay at the opposite direction (Figure 2). Their associa- tion with respect to processes occurring in the soil may suggest a negative correlation.

Plot exhibits an association of sand fractions to the Southeast Sulawesi (Figure 2), which means that sands may strongly contribute to the existing soil characteristics in this region. A pronounced sand characters is suggested to be attributable to parent material composition as identified briefly in the previous section. Sand containing minerals such as quartzite is dominant especially in the western part of this region (Rusmana et al., 1993b).

Conversely, the analysis demonstrates a strong connection of clay to the South Sulawesi. The high clay is supposed to be deposited from sedimentary materials (Sukamto, 1982). Additionally, as clay and basic minerals such as $\mathrm{K}, \mathrm{Ca}$, and $\mathrm{Mg}$, plot together in the same space, they may pose a strong correlation each other. Both materials may be subject to the same processes during deposition, and their high mobility is facilitated through water flow. In the lowland, they will stop to move giving rise to their relative accumulation in the soil columns. Furthermore, basic minerals may be originated from marl and limestone rocks which are found to be available in this region (Sukamto, 1982).

Table 2. Factor pattern for the first five principal components

\begin{tabular}{|c|c|c|c|c|c|}
\hline & $\mathrm{PC} 1$ & $\mathrm{PC} 2$ & PC3 & $\mathrm{PC} 4$ & PC5 \\
\hline Sand & 0.506 & 0.237 & -0.409 & -0.239 & 0.045 \\
\hline Silt & -0.113 & 0.435 & 0.199 & 0.592 & 0.001 \\
\hline Clay & -0.435 & -0.488 & 0.278 & -0.112 & -0.039 \\
\hline Organic C & -0.068 & 0.215 & -0.033 & -0.370 & 0.258 \\
\hline $\mathrm{N}$ & -0.114 & 0.108 & -0.055 & -0.202 & -0.729 \\
\hline $\mathrm{K}$ & -0.254 & -0.213 & -0.479 & -0.144 & 0.032 \\
\hline $\mathrm{Ca}$ & -0.343 & 0.255 & -0.227 & -0.152 & 0.078 \\
\hline $\mathrm{Mg}$ & -0.429 & 0.327 & -0.120 & -0.087 & 0.019 \\
\hline $\mathrm{SO}_{4}$ & -0.073 & 0.029 & -0.393 & 0.294 & -0.468 \\
\hline $\mathrm{Fe}$ & -0.268 & -0.084 & -0.256 & -0.044 & 0.186 \\
\hline $\mathrm{Cu}$ & -0.279 & 0.400 & 0.106 & -0.003 & 0.083 \\
\hline $\mathrm{Zn}$ & 0.019 & 0.263 & 0.320 & -0.419 & -0.032 \\
\hline $\mathrm{pH}\left(\mathrm{H}_{2} \mathrm{O}\right)$ & 0.061 & 0.062 & 0.284 & -0.294 & -0.358 \\
\hline
\end{tabular}


A positive correlation between basic cations, i.e. $\mathrm{K}, \mathrm{Ca}$, and $\mathrm{Mg}$ with residual minerals such as $\mathrm{Fe}$, and $\mathrm{Cu}$ as indicated in the plot (Figure 2), however, is supposed to be regulated through different ways. A common negative correlation between the two is based on the assumption that $\mathrm{Fe}$ and $\mathrm{Cu}$ is immobile, and retained in the soil columns after the washing of some basic minerals out of soil column together with the flow of water.

Therefore, it is high likely that an indirect positive relationship between $\mathrm{K}, \mathrm{Ca}$, and $\mathrm{Mg}$, and $\mathrm{Fe}$ and $\mathrm{Cu}$ may be two different processes in response to various composition, and origin of parent rocks in the same region. As soil samples were collected from different soil types developed on different parent rocks, however, they may reflect to the soil characteristics differently.

Provided that the high coefficient variable for PC1, i.e. sand, clay, $\mathrm{K}, \mathrm{Ca}, \mathrm{Mg}, \mathrm{Fe}$, and $\mathrm{Cu}$ are typical for different parent materials, thus they are considered to determine specific condition of soil properties. As sand and clay fractions pose dominant characteristics in this component, it is considered to define "soil texture" as a factor that may correspond to the PC1.

The high coefficients for $\mathrm{PC} 2$ are given to sand, silt, clay, organic $\mathrm{C}, \mathrm{K}, \mathrm{Ca}, \mathrm{Mg}, \mathrm{Cu}$, and $\mathrm{Zn}$ (Table 2). A pronounced contribution of organic $\mathrm{C}$ is likely due to crop management such as crop residues, and organic matter applications. Similar to PC1, sand and clay, which are associated to Southeast, and South Sulawesi region, have explained the variation in the PC2. Their association with parent materials have been discussed earlier. Furthermore, the analyses shows a strong association of silt to Central Sulawesi region (Figure 2). The potential silt characteristics derived from parent materials have been indicated after former research through the identification of Puna formation existence. This geological formation has been identified as source of silt materials (Simandjuntak et al., 1997).
Silt was found to exhibit a mutual dependence with $\mathrm{Ca}$ and $\mathrm{Mg}$ as they occur at the same space in the plot. Conversely, atypical negative correlation revealed between $\mathrm{Ca}$ and $\mathrm{Mg}$, with $\mathrm{K}$ as defined by PC2 may indicate different processes taking place among regions (Figure 2). This means that to some cocoa farms $\mathrm{Ca}$ and $\mathrm{Mg}$ may be dominantly accumulated in the soil columns, but different farms may pose an existence of $\mathrm{K}$ in a greater part. Among these basic minerals, $\mathrm{Mg}$ demonstrates a highest coefficient indicating a strong parent rock influence.

The presence of heavy minerals of $\mathrm{Cu}$ and $\mathrm{Zn}$ may be associated with parent rocks from which they are derived, such typically as igneous and sedimentary rocks (Havlin et al., 2005), as they mostly occur nearby parent rocks (Birkeland, 1999) being residual products following soil weathering. These minerals exhibit, mostly, a different response to every PCs (Table 2) implying different parent rock origins responsible for their abundance in every regions.

Similar to PC1, as sand, silt and clay fractions play a significant role in the context of variation in this component, therefore it is suggested to define PC2 as "soil texture".

Some variables, i.e. sand, clay, $\mathrm{K}, \mathrm{Ca}, \mathrm{SO}_{4}$, $\mathrm{Fe}, \mathrm{Zn}, \mathrm{pH}\left(\mathrm{H}_{2} \mathrm{O}\right)$, are considered to explain the variation in the PC3. Different to former PC's, the nature of acid condition is occurred in this component due to the presence of $\mathrm{SO}_{4}$ and $\mathrm{pH}\left(\mathrm{H}_{2} \mathrm{O}\right)$ as high coefficient variables. The high coefficient of $\mathrm{SO}_{4}$, with concomitant low for organic $\mathrm{C}$, indicates the presence of acid parent rock effects as confirmed after revealed a negative relation to $\mathrm{pH}\left(\mathrm{H}_{2} \mathrm{O}\right)$. However, the association of $\mathrm{SO}_{4}$ to basic minerals, i.e. $\mathrm{K}, \mathrm{Ca}$, and $\mathrm{Mg}$, are unexpected since both normally available in the soil at contrasting level of $\mathrm{pH}\left(\mathrm{H}_{2} \mathrm{O}\right)$. In this case, atypical effect of basic minerals to $\mathrm{pH}\left(\mathrm{H}_{2} \mathrm{O}\right)$ may be overshadowed by the high concentration of $\mathrm{SO}_{4}$. As discussed earlier, an indirect correlation 

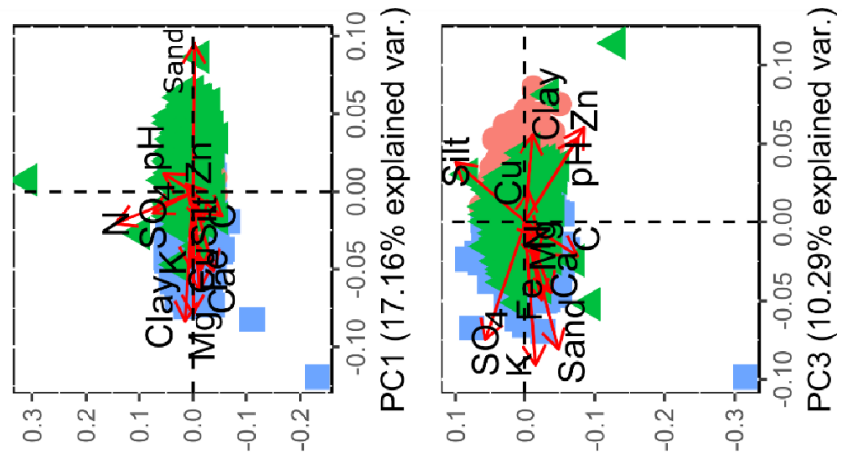

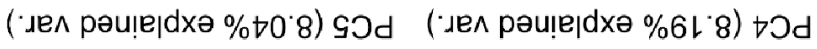
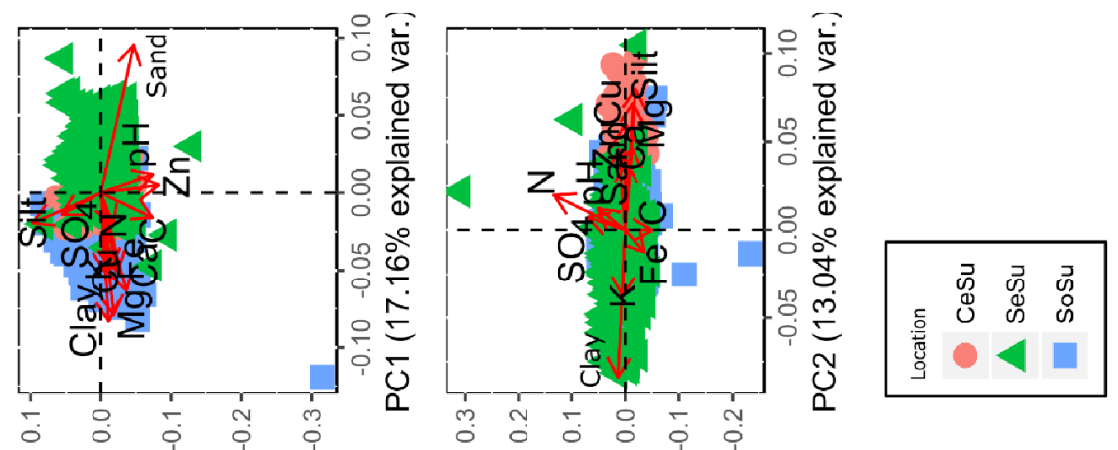

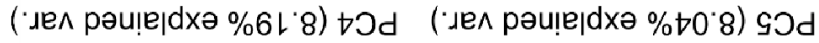
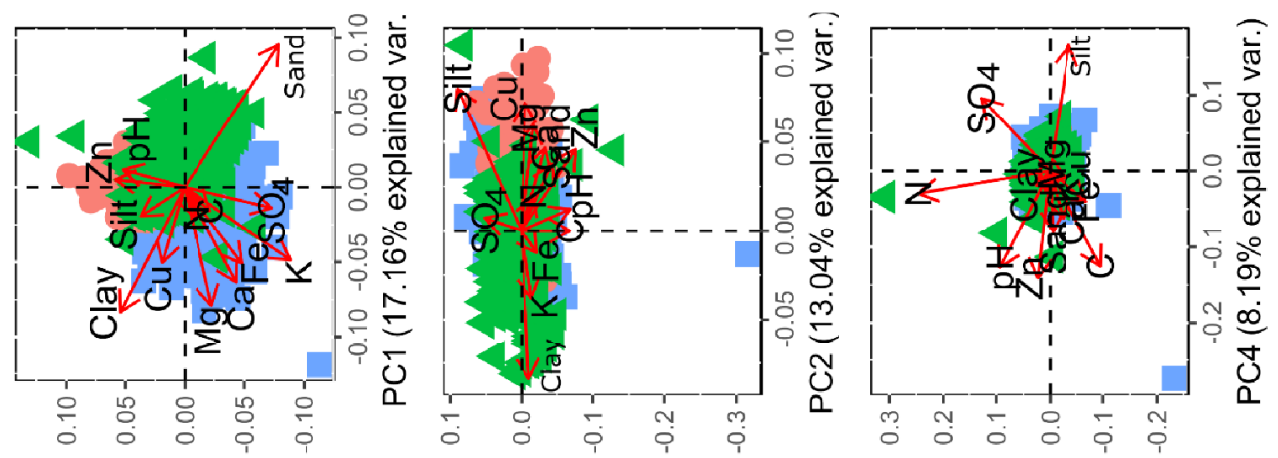

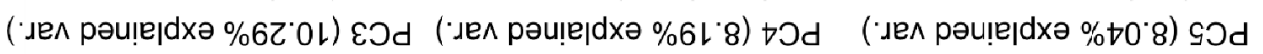
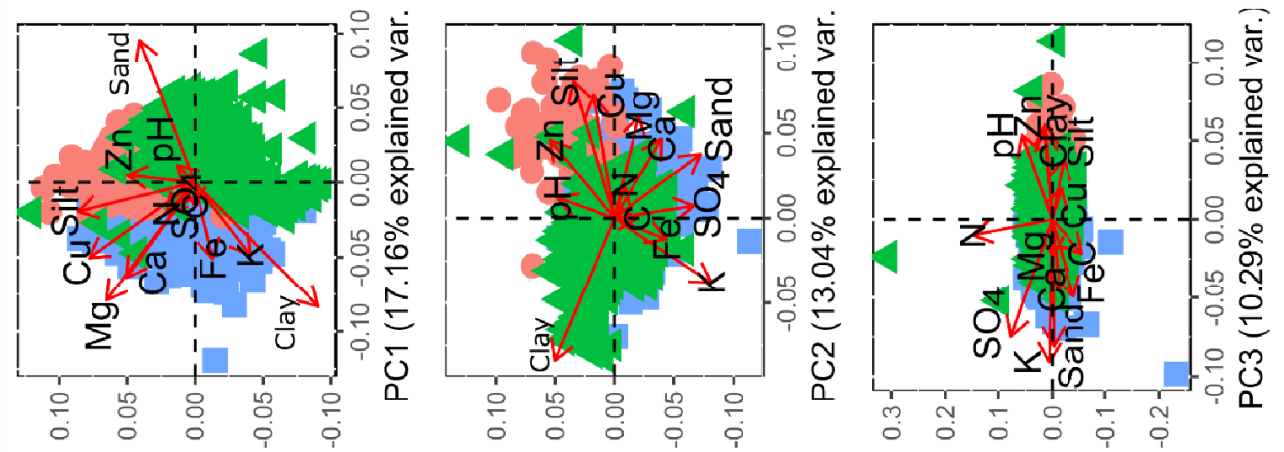

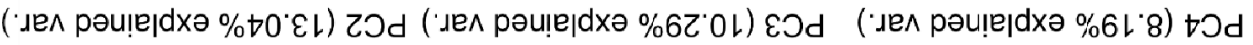

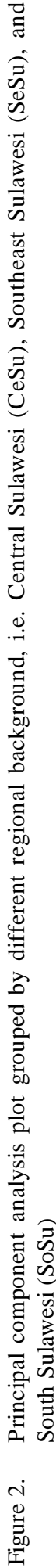


may also exist due to the high variability soil characteristics (Table 1) with different key factors from region to region.

A low and high acid conditions are associated to South and Southeast Sulawesi parent materials, as indicated through plot (Figure 2). From the discussion above, it quite clear connection between soil variable properties and parent rock origins in PC3. Therefore, it is suggested to relate a PC3 as "parent material" factor.

The high coefficients for fourth components were given to some variables, i.e. sand, silt, organic $\mathrm{C}, \mathrm{N}, \mathrm{SO}_{4}, \mathrm{Zn}$, and $\mathrm{pH}\left(\mathrm{H}_{2} \mathrm{O}\right)$. Sands, which are associated to Southeast Sulawesi region, is likely coming from specific parent material such as quartzite (Rusmana et al., 1993b). Similarly, the silt fraction is most likely derived from parent rocks, for instance, on Puna formation in Central Sulawesi (Simandjuntak et al., 1997). The high coefficient for organic $\mathrm{C}$ may indicate the effect of cocoa management such as manure and organic residues application. Organic $\mathrm{C}$ pose a mutual dependence to $\mathrm{pH}\left(\mathrm{H}_{2} \mathrm{O}\right)$, yet negatively correlated to $\mathrm{SO}_{4}$ (Figure 2). The presence of strong $\mathrm{Zn}$ influence for $\mathrm{PC} 4$ may be attributable to parent rock types, for instance $\mathrm{ZnFe}_{2} \mathrm{O}_{4}, \mathrm{ZnCO}_{3}$, and $\mathrm{ZnSiO}_{4}$ (Havlin et al., 2005). Therefore, it can be concluded that the effects of parent rocks are pronounced in this component as well. Thus, it is suggested to define "parent material" as fourth factor.

For PC5, some variables are considered to exhibit high coefficients, i.e. organic $\mathrm{C}, \mathrm{N}$, $\mathrm{SO}_{4}$, and $\mathrm{pH}\left(\mathrm{H}_{2} \mathrm{O}\right)$. The pronounced contribution of organic $\mathrm{C}$ and $\mathrm{N}$ may be interpretable as the result of organic material applications in the farms. Conversely, atypical negative correlation for organic $\mathrm{C}$ and $\mathrm{N}$ is unexpected (Figure 2; Table 2), and unable to confirm in the present research. The extent of organic $\mathrm{C}$ and $\mathrm{N}$ amplitude are likely different from site to site, as suggested by the high field heterogeneity such as crop management, and slope variations. The high variability of organic $\mathrm{C}$ and $\mathrm{N}$ may be reflected through the high CV values of up to $40 \%$ (Table 1).

The plot indicates a positive association between $\mathrm{SO}_{4}$ and $\mathrm{pH}\left(\mathrm{H}_{2} \mathrm{O}\right)$ (Figure 2), which suggests an indirect relationship. This means that there is a chance for other variables to determine the level of $\mathrm{pH}\left(\mathrm{H}_{2} \mathrm{O}\right)$ in the soil other than $\mathrm{SO}_{4}$. As occurred in the same space (Figure 2), $\mathrm{N}$ poses to correlate positively with $\mathrm{pH}\left(\mathrm{H}_{2} \mathrm{O}\right)$.

\section{Distribution of Soil Characteristics}

\section{Clay}

Clay fractions may not only indicate the parent rock origins (Birkeland, 1999), but also the environmental conditions such as climate, landform, and drainage properties at which soil undergoes the development, and the main processes that dominantly taking place. In this section we will not discuss for other soil fractions, i.e. silt and sand due to their lower contribution to soil processes.

The map shows that the high abundance of clays attributable to cocoa farm investigated in South Sulawesi (Figure 3a). As intermontane plains are majority in this area (Figure 1a), the high clays may be deposited through sediment materials from the upper slopes. As latosolization may be accelerated in the western part of South Sulawesi due to high rainfall intensity (Sunarminto, 2000), the connection between these two variables may not be strongly observed in different part of the region (Figure 1c; Figure 3a). The presence of factors other than climate for clay production has been recognized (Birkeland, 1999). We suggest that in this case parent materials play a significant role to clay productions. The high abundance of clay with correspond to a dominant of $\mathrm{K}$ in the soil (Figure 3e), as suggested by PCA 
analyses (Figure 2), may indicate the majority of K-rich clay mineral types such as illite groups.

Conversely, the area with low clay content, down to $4.08 \%$ (Figure 3a), is distributed to the coastal lowland cocoa farms as expected. The low clay in this area may be attributable to the dominant of sand fractions due to the lower level of soil weathering stage.

\section{Organic C and total $N$}

The majority of middle to high level of organic $\mathrm{C}$ in the farms are distributed in the Central Sulawesi (Figure $3 b$ ). As organic $C$ is directly connected to organic source materials, therefore its dynamic distribution is highly probable related to the field cocoa management such as manuring, composting, and mineral fertilization. The connection between the extent of cocoa farms and organic $\mathrm{C}$ abundance in the soil may be supported by statistics that showing the existence of largest cocoa farms in Central Sulawesi, accounting for $29.83 \%$ out of totally $949.70 \mathrm{Ha}$ area in Sulawesi (SDECS, 2018).

The lower extent of soil organic C may be observed in the southern part of Sulawesi (Figure 3b). The PCA analysis did not reveal any common mutual dependence between organic $\mathrm{C}$ and clay (Figure 2; Table 2), which means that the presence of clay-fixed form of organic $\mathrm{C}$ in the soil is likely low.

Additionally, the total $\mathrm{N}$ distributed in all cocoa farms is observed low $(<0.28 \%)$. Its connection to organic $\mathrm{C}$, based on the analysis from separate variable maps (Figure 3b; Figure $3 c$ ), is not really clear since, generally, a regional trend with respect to its distribution is missing. This result may have confirmed the PCA analysis in the previous discussion (Figure 2; Table 2). The analyses demonstrate that some area in the coastal lowland, and mountainland subject to $\mathrm{N}$ depletion (Figure 3c).
Their low $\mathrm{N}$ standing may be either related to the low inherent soil fertility level or the low level of decomposition degree.

\section{Basic cations (K, Ca, and Mg)}

Generally, the K standing for cocoa farms in the study area is ranging from low to moderate ( $<1.2 \mathrm{me} / 100 \mathrm{~g}$ soil). A slightly high soil $\mathrm{K}$ content is observed in the South Sulawesi with subsequent decreasing in Southeast, and Central Sulawesi (Figure 3e). Their distribution may be similar to the boundary created by Palu-Koro-Matano faults separating the southern and northern part of the island (White et al., 2017). As discussed before, the high abundance of $\mathrm{K}$ in the cocoa soil sample collected from South Sulawesi is highly probable connected to parent rocks composition. The K rich environment may give rise to the development of specific type of Krich-clays such as illite, which is not be able to confirm in this research.

The high status of $\mathrm{Ca}(>10 \mathrm{me} / 100 \mathrm{~g}$ soil) is observed in Central Sulawesi and South Sulawesi, whereas low to moderate (5.3-10 me/100 g soil) in Southeast Sulawesi (Figure 3f). The identified limestone or marl as the original parent rocks may responsible for the absolute amount and distribution of soil $\mathrm{Ca}$ in the study areas, as discussed in the previous section. The existence of limestone and other Ca-bearing-rocks in the study area have been reported (Sukamto, 1982; Rusmana et al., 1993a; Simandjuntak et al., 1991; Simandjuntak et al., 1997; Rusmana et al., 1993b; Simandjuntak et al., 1993a; Simandjuntak et al., 1993b).

Data show the high level of soil $\mathrm{Mg}$ (>1.5 me/100 $\mathrm{g}$ soil) in the cocoa farms observed in the three regions. The maps (Figure $3 \mathrm{f}$ and $3 \mathrm{~g}$ ) reveal a similarity of gradients for $\mathrm{Mg}$ and $\mathrm{Ca}$ indicating an association with respect to their origins and soil development processes. As lower level for 


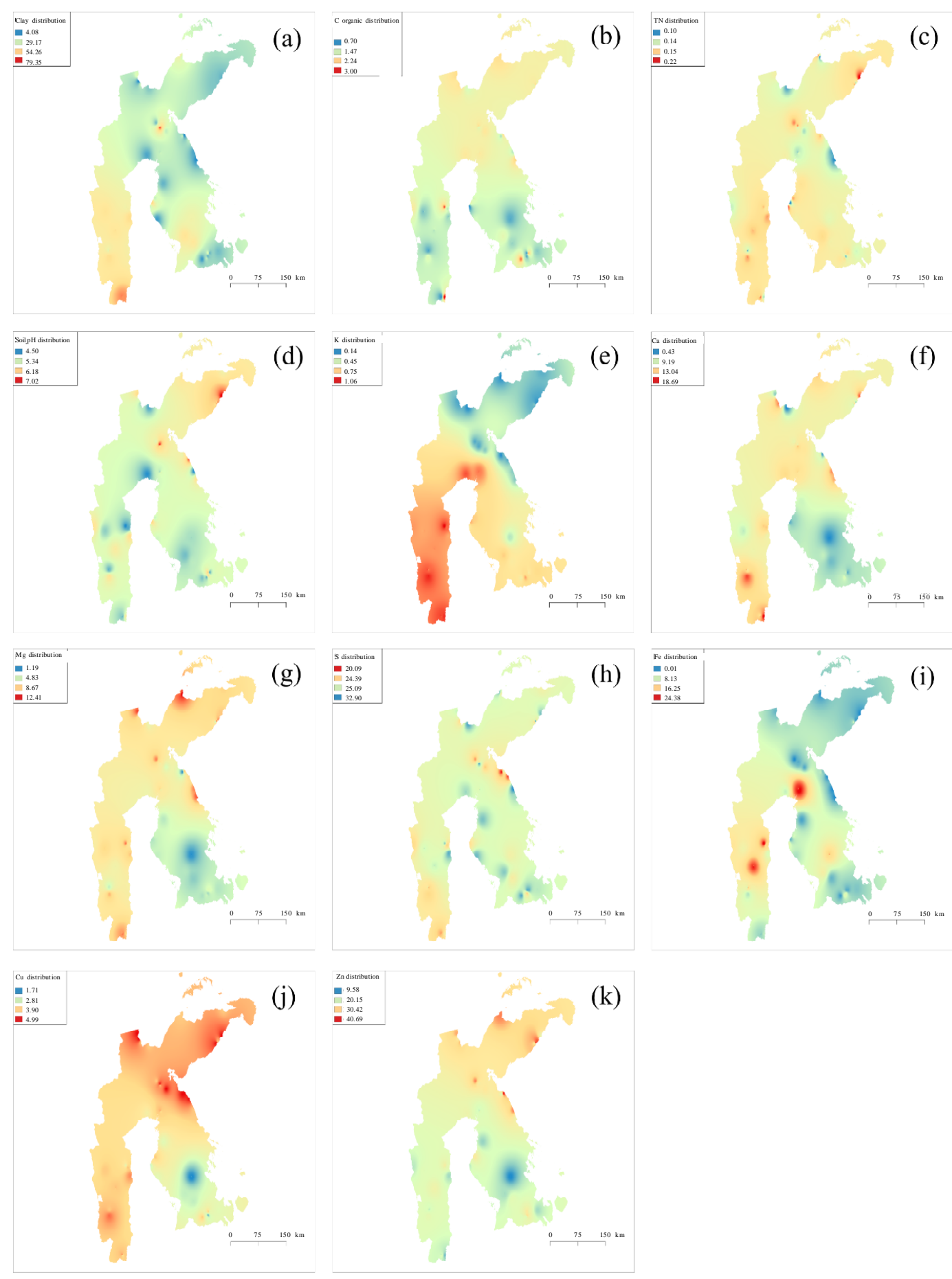

Figure 3. The map of soil characteristics distribution, (a) clay (\%), (b) organic $\mathrm{C}(\%)$, (c) total $\mathrm{N}(\%)$, (d) $\mathrm{pH}\left(\mathrm{H}_{2} \mathrm{O}\right),(\mathrm{e})$ potassium (me/100 g), (f) calcium (me/100 g), (g) magnesium (me/100 g), (h) sulphate $(\mathrm{mg} / \mathrm{kg})$, (i) iron $(\mathrm{mg} / \mathrm{kg})$, (j) copper $(\mathrm{mg} / \mathrm{kg})$, and $(\mathrm{k})$ zinc $(\mathrm{mg} / \mathrm{kg})$ 
both minerals are associated to Southeast Sulawesi, it is suggested to account on the presence of some low $\mathrm{Ca}-\mathrm{Mg}$ bearing parent rocks. They are often to be associated with ultramafic parent materials in this region (Alam, 2012). The strong association between the two minerals has been identified through PCA as discussed in the previous section (Figure 2). This may have confirmed that the same parent rock origins for both minerals existed.

\section{Sulphate and $\mathrm{pH}$}

The high amount of $\mathrm{SO}_{4}$ are mostly distributed to the coastal lowland area (Figure $3 \mathrm{~h}$ ). It may be derived from $90 \%$ of organic and $10 \%$ of mineral sources. e.g. metal sulfide (Havlin et al., 2005). As located in the lowland coastal area, the production of sulphur may have supported by sea water intrusion. The distribution of $\mathrm{SO}_{4}$ is, however, slightly independent to geological setting of the area as indicated by maps (Figure $3 \mathrm{~h}$ ).

The distribution of $\mathrm{pH}\left(\mathrm{H}_{2} \mathrm{O}\right)$ as revealed by map (Figure $3 \mathrm{~d}$ and $3 \mathrm{~h}$ ) indicates a strong association with $\mathrm{SO}_{4}$. A negative correlations between the two variables have been discussed in the previous section (Figure 2). A high $\mathrm{pH}\left(\mathrm{H}_{2} \mathrm{O}\right)$ value for cocoa farms in the coastal area eastern part of Central Sulawesi indicates a neutral to basic environmental background. Additionally, the influence of parent materials to soil acidity status may be observed through a separate line produced on map between northeast and southwest region of study area (Figure 3d).

\section{Micronutrients}

Similar to K distribution, geological faults separation occurring in the middle of island may split the micronutrient distributions, i.e. $\mathrm{Fe}, \mathrm{Cu}$, and $\mathrm{Zn}$, into southern and northern part of Sulawesi regions. The amount of $\mathrm{Fe}$ is slightly higher in the South and Southern part of Sulawesi than in the Central Sulawesi (Figure 3i). Conversely, the abundance of $\mathrm{Cu}$ and $\mathrm{Zn}$ are higher in the Central Sulawesi cocoa farms with a similar lateral gradient (Figure 3j, Figure 3k).

As heavy minerals are considered to be the residue materials during soil development processes (Birkeland, 1999), it means that they do not move away in the soil system, instead of accumulating in the immediate vicinity of soil parent rocks. Therefore, their extent in the soil depend largely on the parent material types and compositions.

\section{CONCLUSIONS}

Our data indicate a high variability of most soil characteristics with CV of up to about $118 \%$ for Fe in the study area in Central Sulawesi, South Sulawesi, and Southeast Sulawesi. The soil $\mathrm{pH}\left(\mathrm{H}_{2} \mathrm{O}\right)$ shows the only variable with a high homogeneity among cocoa farms with CV of about $10 \%$. Statistical evaluation of cocoa soil characteristics through a principal component analysis revealed that soil texture, i.e. sand, silt, and clay, factor plays an important role in determining the $\mathrm{PC} 1$ and PC2. Different region shows a specific character in relation to soil particle compositions. Regionally, sands are associated to Southeast Sulawesi, silts to Central Sulawesi, and clays to South Sulawesi. Further analysis points out the parent material as a factor to define PC3, PC4, and PC5. In the present research, parent materials represent some mineral variables mainly $\mathrm{K}, \mathrm{Ca}, \mathrm{Mg}, \mathrm{Fe}$, and $\mathrm{Zn}$. Soil characteristic gradients provided by soil map indicate a strong connection between landform and geological setting. Regional landforms, as a result of geomorphological processes, may have determined the lateral distribution of several soil variables such as organic $\mathrm{C}$, and total $\mathrm{N}$ in the intermontane plains, and $\mathrm{SO}_{4}$ in the lowland coastal area. Additionally, 
geological setting is likely responsible to the mineral gradients such as $\mathrm{K}, \mathrm{Ca}, \mathrm{Mg}, \mathrm{Fe}$, $\mathrm{Cu}$, and $\mathrm{Zn}$ as well as $\mathrm{pH}\left(\mathrm{H}_{2} \mathrm{O}\right)$ in different geological formation.

\section{REFERENCES}

Alam, S.; B.H. Sunarminto \& S.A. Siradz (2012). Characteristics of soil parent materials complex ultramafic geological formations in Southeast Sulawesi. Jurnal Agroteknos, 2, 112-120.

Arshad, A.M.; H.M.E. Armanto \& H.Y. Rawayau (2016). The effect of soil parent materials on yield of cocoa. Journal of Natural Science Research, 6, 37-43.

Astel, A.M.; L. Chepanova \& V. Simeonov (2011). Soil contamination interpretation by the use of monitoring data analysis. Water Air Pollution, 216, 375-390.

Birkeland, P.W. (1999). Soils and Geomorphology. Oxford University Press. Oxford.

Bitencourt, D.G.B.; W.S. Barros; L.C. Timm; D. She; L.H. Penning; J.M.B. Parfitt \& K. Reichardt (2016). Multivariate and geostatistical analysis to evaluate lowland soil levelling effects on physicochemical properties. Soil \& Tillage Research, 156, 63-73.

Buurman, P.; M.C. Amézquita \& H.F. Ramirez (2008). Factors Affecting Soil C Stocks: A Multivariate Analysis Approach. p. 91-101. In: Carbon Sequestration in Tropical Grassland Ecosystems ('t Mannetje, L., M. C. Amézquita, P. Buurman \& M. A. Ibrahim, Eds)., Wageningen Academic Publishers. Wageningen, Netherland.

Eviati \& Sulaeman (2009). Analisis Kimia Tanah, Tanaman, Air, dan Pupuk. Balai Penelitian Tanah. Bogor.

Everitt, B. \& T. Hothorn (2011). An Introduction to Applied Multivariate Analysis with $R$. Springer, New York.

Fernandez-Moya, J.; A. Alvarado; M. Morales; A.S. Miguel-Ayanz \& M. MarchamaloSacristan (2014). Using multivariate analysis of soil fertility as a tool for forest fertilization planning. Nutrient Cycle Agroecosytem, 98, 155-167.

Fick, S.E. \& R.J. Hijmans (2017). Worldclim 2: New 1-km spatial resolution climate surfaces for global land areas. International Journal of Climatology.

Hartemink, A.E. (2005). Nutrient stock, nutrient cycling, and soil changes in cocoa ecosystem: A Review. Advance in Agronomy, 86, 227-253.

Havlin, J.L.; J.D. Beaton; S.L. Tisdale \& W.L. Nelson (2005). Soil Fertility and Fertilizers. An Introduction to Nutrient Management. Prentice Hall. New Jersey.

Hikmatullah \& Suparto (2014). Characteristics of paddy soils from lacustrine deposit in Sulawesi. Jurnal Tanah dan Iklim, 38, $1-14$.

Jones, J.B.; B. Wolf \& H.A. Mils (1991). Plant Analysis Handbook. A Practical Sampling, Preparation, Analysis and Interpretation Guide. Macro-Micro Publishing, Inc.

Karydas, C.G.; I.Z. Gitas; E. Koutsogiannaki; N. L-Simantiris \& G.N. Silleos (2009). Evaluation of spatial interpolation techniques for mapping agricultural topsoil properties in Crete. EARSeL eProceedings 8.

Katili, J.A. (1978). Past and present geotectonic position of Sulawesi, Indonesia. Tectonophysics, 45, 289-322.

Kosaki, T. \& A.S.R. Juo (1989). Multivariate approach to grouping soils in small fields. I. Extraction of factors causing soil variation by principal component analysis. Soil Science and Plant Nutrition, 35, 469-477.

Martosuwito, S (2012). Tectonostratigraphy of the eastern part of Sulawesi, Indonesia in relation to the terrane origins. JSD Geology, 22, 199-207.

Maskar; Syarifuddin \& S. Abdoellah (1999). Soil nutrient status of cocoa smallholdings in Central Sulawesi. Pelita Perkebunan, $15,22-32$. 
McKillup, S. (2012). Statistics Explained. An Introductory Guide for Life Scientists. Cambridge University Press.

Robinson, T.P. \& G. Metternicht (2006). Testing the performance of spatial interpolation techniques for mapping soil properties. Computers and Electronics in Agriculture, 50, 97-108.

Rusmana, E.; A. Koswara \& T.O. Simandjuntak (1993a). Geological Map of the Luwu Sheet 1:250.000. Geological Research and Development Centre. Bandung.

Rusmana, E.; Sukido; D. Sukarna; E. Haryono \& T.O. Simandjuntak (1993b). Geological Map of the Lasusua-Kendari Quadrangle 1:250.000. Geological Research and Development Centre. Bandung.

Safiuddin, L.O.; V. Haris; R.P. Wirman \& S. Bijaksana (2011). A preliminary study of the magnetic properties on laterite soils as indicators of pedogenic processes. Latinmag Letters, 1, 1-15.

Setianto, A. \& T. Triandini (2013). Comparison of kriging and inverse distance weighted (IDW) interpolation methods in lineament extraction and analysis. J. SE Asin Appl. Geol., 5, 21-29.

Simandjuntak, T.O.; E. Rusmana; Surono \& J.B. Supandjono (1991). Geological Map of Malili Quadrangle, Sulawesi 1:250.000. Geological Research and Development Centre. Bandung.

Simandjuntak, T.O.; E. Rusmana; J.B. Supandjono \& A. Koswara (1993a). Geological Map of Bungku Quadrangle, Sulawesi 1:250.000. Geological Research and Development Centre. Bandung.

Simandjuntak, T.O.; Surono \& Sukido (1993b). Geological Map of Kolaka Sheet, Sulawesi 1:250.000. Geological Research and Development Centre. Bandung.
Simandjuntak, T.O.; Surono \& J.B. Supandjono (1997). Geological Map of the Poso Quadrangle, Sulawesi 1:250.000. Geological Research and Development Centre. Bandung.

SDECS (2018). Indonesian Cocoa Statistics 2017. Sub Directorate of Estate Crops Statistics, BPS-Statistics Indonesia.

Sukamto, R. (1982). Geological Map of the Pangkajene and Western Part of Watampone Quadrangle, Sulawesi 1:250.000. Geological Research and Development Centre. Bandung.

Sunarminto, B.H. (2000). Genesis oxisols and ultisols on dunit parent materials in Malili, South Sulawesi. Jurnal Ilmu Tanah dan Lingkungan, 2, 43-52.

Swan, A.R.H. \& M. Sandilands (1995). Introduction to Geological Data Analysis. Blackwell Science. Wien.

van Bemmelen, R.W. (1942). The Geology of Indonesia. Martinus Nijhoff, The Hague.

Wagai, R.; L.M. Mayer; K. Kitayama \& H. Knicker (2008). Climate and parent material controls on organic matter storage in surface soils: A three-pool, densityseparation approach. Geoderma, 147, 23-33.

White, L.T.; R. Hall; R.A. Armstrong; A.J. Barber; M.B. Fadel; A. Baxter; K. Wakita; C. Manning \& J. Soesilo (2017). The geological history of the Latimojong region of western Sulawesi, Indonesia. Journal of Asian Earth Sciences, 138, 72-91.

Yatno, E.; Sudarsono; B. Mulyanto \& Iskandar (2015). Characteristics of soils formed from schist and their land suitability for cocoa: a case study in Southeast Sulawesi. Jurnal Tanah dan Iklim, 39, 109-120. $* * 0 * *$ 